WHAT ROLE FOR THE EUROPEAN PARLIAMENT UNDER ARTICLE 50 TEU? ${ }^{* * *}$

Word Count $=9469$

Word Count with changes $=8877$

\begin{abstract}
:
Following the United Kingdom's vote to leave the European Union in a national referendum there has been much debate over the correct legal process to be followed under both domestic law and the EU Treaties to give effect to this decision. This paper seeks to contribute to these discussions by focusing on an aspect of the withdrawal process which, in the author's view, has not been given full consideration to date; namely, the need for the consent of the European Parliament before any withdrawal agreement may be completed.
\end{abstract}

Keywords:

Withdrawal from the European Union, Article 50 TEU, European Parliament, EU Treaties, Brexit

\title{
Introduction
}

Following the United Kingdom's (UK) decision to vote to leave the European Union (EU) in a national referendum on $23^{\text {rd }}$ June 2016, the focus of many in the legal academic community immediately turned to the process by which a "Brexit" may become a reality. Much debate has been generated around Article 50 Treaty on European Union (TEU) which sets down the procedure that a Member State must follow in order to first notify the European Council of its intention to withdraw and subsequently negotiate a withdrawal agreement with the EU. ${ }^{1}$ In particular, the question of how the UK may notify its intention to withdraw in a manner that is in line with its own domestic constitutional requirements has generated much discussion. ${ }^{2}$

\footnotetext{
${ }_{*}^{*}$ Darren Harvey, PhD Candidate in Law, Darwin College, Cambridge

** A shorter version of this article appeared in blog post format, see Darren Harvey, 'What Role for the European Parliament under Article 50 TEU?' EU Law Analysis Blog, Thursday, 14 July 2016, available at: http://eulawanalysis.blogspot.lu/2016/07/what-role-for-european-parliament-under.html

${ }^{1}$ The relevant provision is found in Article 50(1) Treaty on European Union (TEU) and reads as follows: 'Any Member State may decide to withdraw from the Union in accordance with its own constitutional requirements.'

${ }^{2}$ For an overview of, and contribution to, this debate see Mark Elliott, 'On why, as a matter of law, triggering Article 50 does not require Parliament to legislate', Public Law for Everyone Blog, 30 June 2016, available at: https://publiclawforeveryone.com/2016/06/30/brexit-on-why-as-a-matter-of-law-triggering-article-50-does-notrequire-parliament-to-legislate/.
} 
Moreover, from a different perspective, the question of whether the devolved governments in the United Kingdom (in particular Scotland) may somehow block the UK government's move to either initiate the process of withdrawing from the EU or conclude a withdrawal agreement has been considered. ${ }^{3}$

The purpose of this post is to contribute to the ongoing debate surrounding the UK and Article 50 TEU by focusing on an aspect of the withdrawal process which has not been given full consideration to date; namely, the need for consent of the European Parliament before any withdrawal agreement may be completed. ${ }^{4}$

\section{Background and Legal Framework}

Since the Single European Act, a number of Treaty articles have mandated that proposed acts of EU law require the consent of the European Parliament before they may enter into force - thus giving the Parliament a de facto right of veto in certain situations. ${ }^{5}$ This power was widened following the entry into force of the Lisbon Treaty, with the consent of the European Parliament now being required across a variety of EU policy fields including the conclusion of many international agreements in key areas such as trade, agriculture and security matters - all of which it had previously been excluded from. ${ }^{6}$

Under Article 50(2) TEU, the consent of the European Parliament is required before a withdrawal agreement may enter into force. The relevant provision reads as follows:

"A Member State which decides to withdraw shall notify the European Council of its intention. In the light of the guidelines provided by the European Council, the Union shall negotiate and conclude an agreement with that State, setting out the arrangements for its withdrawal, taking account of the framework for its future relationship with the Union. That agreement shall be negotiated in accordance with Article 218(3) of the Treaty on the Functioning of the European Union. It shall be concluded on behalf of the Union by the Council, acting by a qualified majority, after obtaining the consent of the European Parliament."7

\footnotetext{
3 J. Murkens, 'Brexit: The Devolution Dimension', U.K. Const. L. Blog, 28th Jun 2016, available at https://ukconstitutionallaw.org/); Robert Hazell and Alan Renwick, 'Brexit: Its Consequences for Devolution and the Union' UCL Constitution Unit Briefing Paper No.3, May 2016, available at: https://www.ucl.ac.uk/constitutionunit/research/europe

${ }^{4}$ For a brief discussion of the role of the European Parliament prior to the UK's vote to leave the EU see House of Lords European Union Committee, 'The process of withdrawing from the European Union', 11th Report of Session 2015-16, HL Paper 138, p. 7-9.

${ }_{6}^{5}$ Lenaerts \& Van Nuffel, European Union Law, (Sweet and Maxwell 2011) p.676.

${ }^{6}$ Ariadna Ripoll Servent, 'The Role of the European Parliament in International Negotiations after Lisbon' (2014) J.E.P.P 21, 568; Chalmers, Davies and Monti, European Union Law, (2014 CUP) 127

${ }^{7}$ Art. 50(2) TEU.
} 
Before moving to analyse the role that the European Parliament may play in the process of negotiating and concluding a withdrawal agreement with the UK under Article 50 TEU, however, it is first necessary to note that there is no legal obligation upon the UK or the EU to conclude such an agreement at all. Whilst the wording of Article 50(2) TEU clearly favours "a negotiated secession as the optimum solution", Member States nevertheless retain the right to unilaterally withdraw from the EU by notifying the European Council of its intention to do so before opting to then simply "sit out two years before its decision becomes final.",

Whereas a clean break from the EU two years after triggering an Article 50 TEU notification is thus possible, it is clear that the UK government will seek some form of negotiation with a view to reaching a withdrawal agreement with the EU. Indeed, at the time of writing, UK Prime Minister Theresa May has indicated that her government intends to notify the European Council of the UK's decision to withdraw from the EU - and thus begin the formal withdrawal process under Article 50 TEU - by the end of March 2017.

Operating in line with the position that Article 50 TEU is the only (legally) plausible way of a Member State withdrawing from the European Union ${ }^{9}$ - and leaving to one side the question of how the Article 50 process may be triggered in accordance with the UK's domestic constitutional requirements in the first place - it is clear from Article 50(3) TEU that once notification to withdraw has been made:

"The Treaties shall cease to apply to the State in question from the date of entry into force of the withdrawal agreement or, failing that, two years after the notification referred to in paragraph $2 . " 10$

In other words, the two-year clock starts ticking from the moment notification is made by the UK of its intention to leave the EU; unless of course "the European Council, in agreement with the Member State concerned, unanimously decides to extend this period." 11

Thus, should no deal be reached within the mandated two-year period, and should no unanimous agreement be reached in the European Council to extend the negotiations, it is clear that the UK's membership of the EU would simply come to an end.

\footnotetext{
${ }^{8}$ A.F. Tatham, "Don't Mention Divorce at the Wedding, Darling!: EU Accession and Withdrawal after Lisbon" in Biondi et al (eds), EU Law After Lisbon, (Oxford 2012) 152; J. Herbst, "Observation on the Right to Withdraw from the European Union: Who are the 'Masters of the Treaties'?" (2005) 6 G.L.J. 1755. For a more 'contextual' approach see A. Łazowski 'Withdrawal from the European Union and alternatives to membership', (2012) E.L.R $37(5), 528$.

${ }^{9}$ K. Armstrong "The Vote Leave Framework for a New UK-EU Deal: Analysis" (2016) CELS Working Paper, No. 3; Eva-Maria Alexandrova Poptcheva "Article 50 TEU: Withdrawal of a Member State from the EU" European Parliament Think Tank Briefing, available at: http://www.europarl.europa.eu/RegData/etudes/BRIE/2016/577971/EPRS BRI(2016)577971 EN.pdf.

${ }^{10}$ Art. 50(3) TEU.

${ }^{11}$ Ibid.
} 
However, in the event that a deal is reached, not only will its entry into force be dependent upon a qualified majority vote in favour in the Council, but also, crucially, prior to such a vote taking place, the consent of the European Parliament is first required.

This requirement of prior consent of the European Parliament under Article 50(2) TEU poses the following two questions: first, how is that consent given? And second, what happens if that consent is not forthcoming?

Before moving to analyse these questions, however, it is first necessary to briefly discuss the likely scope and content of an agreement reached under Article 50 TEU and how this may relate to any future agreement between the UK and the EU.

\section{Two Separate Agreements?}

\section{a.) Overview}

Under Article 50(2) TEU, the Union shall negotiate and conclude a withdrawal agreement with the withdrawing State, "setting out the arrangements for its withdrawal, taking account of the framework for its future relationship with the Union."

It is unclear from this provision whether the agreement concluded within the two-year period following notification under Article 50 TEU will cover arrangements for the UK's withdrawal from the EU and all matters pertaining to future relations between the two parties. ${ }^{12}$

In Łazowski's view, "there are many reasons why a withdrawal agreement should cover both the terms and conditions of exit and future relations." ${ }^{13}$ First, it would secure a smooth transition and reduce legal and economic uncertainties. Moreover, by placing the entire package within one agreement it would only require a single ratification per member state, thus streamlining the ratification process by both the EU and its Member States. ${ }^{14}$

However, at the time of writing, there appears to be a general consensus in the academic commentary that there is indeed a distinction to be drawn between the withdrawal agreement concluded under Article $50 \mathrm{TEU}$, and any future agreement providing for future relations between the withdrawing state and the European Union. ${ }^{15}$ This would also appear to be the view

\footnotetext{
${ }^{12}$ V. Miller and A. Lang, "Brexit: how does the Article 50 process work?", House of Commons Library Briefing Paper Number 7551 (30 June 2016) 25

${ }^{13}$ Adam Lazowski, 'Procedural Steps towards Brexit.' Centre for European Policy Studies (CEPS) Commentary, 13 July 2016, p.3, available at: https://www.ceps.eu/system/files/Procedural\%20steps\%20towards\%20Brexit.pdf. ${ }^{14}$ ibid.

${ }^{15}$ Bruno de Witte, 'Near-membership, partial membership and the EU constitution' (2016) European Law Review, 41(4), 471-472; C. Hillion, "Accession and Withdrawal in the Law of the European Union", in Arnull and Chalmers
} 
of the European Parliament, which noted in a resolution adopted soon after the UK's vote to leave the EU that "any new relationship between the UK and the EU may not be agreed before the conclusion of the withdrawal agreement."16

As Craig notes, "Article 50 is uncharted territory and therefore the content of the withdrawal agreement is uncertain." 17 This applies not only with regards to the exact details of any agreement dealing with the future relationship between the EU and the UK, but also, crucially, "with regard to what is put into the withdrawal agreement and what remains for resolution through some later treaty." 18

According to De Witte, the negotiation and conclusion of two separate agreements could "not really be otherwise", since:

the withdrawal agreement would be concluded by the EU only (without its Member States), whereas the future relationship would necessarily have to be laid down in a treaty to which the Member States are also parties, since that treaty would entail potentially important changes in the existing rights and obligations of all EU States."

Whilst the scope and content of these two agreements will be a matter for the negotiations, it has been suggested that the withdrawal agreement may not entail "far reaching EU commitments in terms of future cooperation with the withdrawing state", but instead be limited to "setting out the arrangements for [the] withdrawal of a technical nature, possibly to areas where the EU has exclusive powers, such as trade."19

In contrast, the future relationship between the UK and the EU is likely to be "left for a more comprehensive agreement, to be negotiated at a later date. ${ }^{, 20}$

What remains to be seen, however, is whether the Article 50 TEU withdrawal agreement will be negotiated and concluded prior to any agreement setting out the future relationship between the EU and the UK, or whether these two deals may be concluded simultaneously?

Ultimately this is a matter that can only be resolved once the Article 50 TEU notification has been made and the negotiation processes have begun. It shall therefore not be dealt with any further here. ${ }^{21}$ Suffice it to say that, given the short two-year time limit and the problems inherent in requiring unanimity to extend the deadline, simultaneous conclusion of both agreements appears unlikely. As a result, it is foreseeable that the withdrawal agreement under Article 50

(eds), The Oxford Handbook of European Union Law (Oxford 2015); Evidence of Sir David Edward and Dereck Wyatt, House of Lords European Union Committee (n 4) 7-9.

${ }^{16}$ European Parliament resolution of 28 June 2016 on the decision to leave the EU resulting from the UK referendum (2016/2800(RSP)).

${ }^{17}$ Paul Craig, 'Brexit: a drama in six acts' E.L. Rev. 2016, 41(4), 447-468, 465.

${ }^{18}$ Ibid.

${ }^{19}$ Hillion (n 17) 140

${ }^{20}$ Hillion (n 17) 140.

${ }^{21}$ For a discussion of these points see Lazowski $(\mathrm{n} 8)$. 
TEU will make provision for some sort of transitional arrangement between the period of withdrawal and the entering into force of any deal regulating future EU-UK relations.

Should this be so, a crucial factor in the withdrawal negotiations will be to reach a deal entailing temporary provisions "extending the scope of certain EU provisions (for example the four freedoms or some of them, or budget rights and obligations) to the 'future former' Member State for a certain amount of time. ${ }^{22}$ It may also deal with matters such as "the movement and treatment of citizens from the withdrawing state, and of citizens from other Member States resident in that state" 23

b.) The European Parliament and the Framework for Future EU-UK Relations.

With regards to the role of the European Parliament in these processes, it is important to note that the degree of involvement in the negotiations and conclusion of the Article 50 TEU withdrawal agreement may differ from that of any agreement detailing future EU-UK relations.

This will depend upon the content and scope of any such agreement and, more importantly, its legal basis in the Treaties.

One possibility is that an agreement setting out the details of the future relationship between the EU and the UK will take the form of an agreement under Article 207 TFEU where it concerns only issues relating to the EU's Common Commercial Policy. Alternatively, and what is more likely, future relations shall be set out in an international agreement under Article 218 TFEU.

According to the first option, Article 207(3) provides that the Commission is obliged only to report regularly to the European Parliament on the progress of negotiations. Furthermore, Article 207(4) TFEU makes it clear that all agreements negotiated by the EU within the scope of the CCP shall be concluded by the Council acting either by unanimity or under QMV. Consequently, without requiring its consent, the European Parliament is likely to have less influence on a EUUK agreement based on Article 207 TFEU than it does under Article 50 TEU.

That being said, the more likely scenario is that any future EU-UK relationship will be set out in an international agreement under Article 218 TFEU. Amongst other things, Article 218(6)(a) TFEU refers to "association agreements" and "agreements with important budgetary implications for the Union" as agreements which require the consent of the European Parliament prior to their conclusion. As a result, should any future EU-UK deal have Article 218 as its legal basis, the Parliament will be in a situation analogous to that laid down in Article 50 TEU.

Of course, much will depend upon the scope and content of the Article 50 TEU withdrawal agreement and any deal reached between the EU and the UK vis their future relations.

\footnotetext{
${ }^{22}$ Hugo Flavier and Sébastien Platon, 'Brexit: A Tale of Two Agreements?', European Law Blog, 30 August 2016, available at: http://europeanlawblog.eu/?p=3324.

${ }^{23}$ Hillion (n 17) 141.
} 
Nevertheless, it is important to note that the influence of the European Parliament over the processes of negotiating and concluding these agreements may differ depending upon their legal basis in the Treaties.

In light of these considerations, the remainder of this paper shall consider the role that the European Parliament may play in the process of negotiating and concluding the withdrawal agreement in Article 50 TEU, whilst remaining cognizant of the fact that this analysis may be relevant to any agreement regulating future EU-UK relations.

\section{The Giving of Parliamentary Consent}

a.) The Default Position

Turning first to the question of how the European Parliament may give its consent to any withdrawal agreement, Article 50(2) TEU merely states that the "consent" of the European Parliament is required before the withdrawal agreement may be put to a vote in the Council.

What constitutes consent in such a situation? The default decision-making rule for the European Parliament is set down in Article 231 Treaty on the Functioning of the European Union (TFEU) which provides:

"Save as otherwise provided in the Treaties, the European Parliament shall act by a majority of the votes cast. The Rules of Procedure shall determine the quorum."24

According to Rule 168(2) of the European Parliament's Rules of Procedure "A quorum shall exist when one third of the component Members of Parliament are present in the Chamber." 25

Whilst one would expect a full chamber to be present for such a vote, it is important to note that, under the default rules, a majority vote based on the participation of the entire chamber is not legally required for Parliament's giving or withholding of consent to be valid.

In the absence of any specific guidance in Article $50 \mathrm{TEU}$, the default rule set out in Article 231 TFEU and accompanying Rules of Procedure mandate that the European Parliament may provide or withhold its consent to any future withdrawal agreement by a simple majority of the votes cast by at least one third of the total number of Members of the European Parliament (MEP).

Accordingly, provided that more than one third of the total members of the European Parliament turn up to vote on any future withdrawal agreement, a simple majority of votes cast shall be sufficient to determine the European Parliament's position.

${ }^{24}$ Art. 231 TFEU.

${ }^{25}$ Rule 168(2), Parliament Rules of Procedure, $8^{\text {th }}$ Parliamentary Term, September 2015. 


\section{b.) Withdrawal Agreements}

But would the default decision-making rule under Article 231 TFEU and the relevant rules of procedure apply to an Article 50 TEU withdrawal agreement?

Rule 82 of the European Parliament's Rules of Procedure is entitled "Withdrawal from the Union." According to that provision:

"If a Member State decides, pursuant to Article 50 of the Treaty on European Union, to withdraw from the Union, the matter shall be referred to the committee responsible...Parliament shall decide on consent to an agreement on the withdrawal by a majority of the votes cast."

As a result, the 'majority of the votes cast' is also the rule governing European Parliamentary consent to withdrawal agreements under Article 50 TEU. Once again, should the entire chamber be present for the vote, a simple majority of votes will be required to give or withhold Parliament's consent.

As to whether a minimum number of votes must be cast to establish the European Parliament's position, Article 82 Rules of Procedure is silent. However, according to Rule 99, Rules of Procedure - which governs Parliament's consent procedures:

"Parliament shall decide on the act requiring its consent under the Treaty on European Union or the Treaty on the Functioning of the European Union by means of a single vote on consent... The majority required for the adoption of the consent shall be the majority indicated in the article of the Treaty on European Union or the Treaty on the Functioning of the European Union that constitutes the legal basis for the proposed act or, where no majority is indicated therein, the majority of the votes cast. If the majority required is not obtained, the proposed act shall be deemed to have been rejected."

As previously indicated, the relevant Treaty article (Article $50 \mathrm{TEU}$ ) gives no indication as to the majority required in order for the Parliament to give its consent to a withdrawal agreement. Therefore, in the absence of any specific stipulation vis-à-vis the threshold for consent in Article 50 TEU, the default rule under Article 231 TFEU applies.

Accordingly, before moving to a Qualified Majority Vote in the Council under Article 50(2) TEU, the European Parliament may vote to give or withhold its consent on the withdrawal agreement by a minimum of a simple majority of one third of its component members.

c.) International Agreements

cut out. -242 words

Whilst the default rule is that Parliament shall act by a majority of the votes cast when giving or withholding consent, certain provisions of the Treaties provide by way of exception that the 
European Parliament may only establish its position following a vote by a majority of its component members. $^{26}$

For example, under the simplified revision procedures set out in Article 48 TEU, certain decisions may be taken unanimously by the European Council "after obtaining the consent of the European Parliament, which shall be given by a majority of its component members."27

Similarly, under the accession procedure set out in Article 49 TEU:

"The applicant State shall address its application to the Council, which shall act unanimously after consulting the Commission and after receiving the consent of the European Parliament, which shall act by a majority of its component members."

Notably, the same stipulation of acting by a majority of its component members was not provided for in Article 50 TEU. This would appear to have been a deliberate choice by the drafters of the Treaty, and leads us to the conclusion that the process by which the European Parliament may give or withhold its consent is different under Article 50 TEU than it is for Articles 48 and 49 TEU.

"It is interesting to note that to join the Union a legal relationship with the current Member States needs to be established, but to leave the Union a Member State will have to settle the issue with the organization of which it has become a member."28

In light of this, it has been noted that:

"agreements on withdrawal are not concluded between the Member States and a future (departing) country, hence they do not form part of EU primary law. This is rather a bizarre anomaly with profound legal consequences for the European Union."29

Thus, whilst a decision to amend the Treaties under Article 48 TEU or conclude an accession agreement under Article 49 TEU would constitute primary EU law, under the EU hierarchy of norms agreements concluded by the Union (including withdrawal agreements) "are situated between primary law (such as the TEU and the TFEU) and legislative acts (such as regulations and directives.)" ${ }^{\prime 30}$

This explains why Articles 48 TEU and 49 TEU require an outright majority of the total number of Parliament's component members to vote to give or withhold Parliament's consent, whereas

${ }^{26}$ R. Schutze, European Constitutional Law, (Cambridge 2012) 94-96.

${ }^{27}$ Art. 48(7) TEU.

${ }^{28}$ B.V. Vooren \& R.A. Wessel, EU External Relations Law (Cambridge 2014) 65.

${ }^{29}$ A Łazowski, (n 8) 529.

${ }^{30}$ Allan Rosas, 'The Status in EU Law of International Agreements Concluded by EU Member States' (2010) 34 Fordham Int'l LJ 1304, 1310, 
Article 50 TEU merely requires a majority of votes cast in the event that more than one third of MEPs participate in the vote.

Furthermore, Article 50(2) TEU provides that any withdrawal agreement must be negotiated in accordance with Article 218(3) TFEU which provides:

The Commission, or the High Representative of the Union for Foreign Affairs and Security Policy where the agreement envisaged relates exclusively or principally to the common foreign and security policy, shall submit recommendations to the Council, which shall adopt a decision authorising the opening of negotiations and, depending on the subject of the agreement envisaged, nominating the Union negotiator or the head of the Union's negotiating team.

As was noted above, any EU-UK agreement governing future relations between the two parties would likely constitute an international agreement for the purposes of Article 218 TFEU. ${ }^{31}$

As a consequence, Rule 108 Rules of Procedure would apply to any agreement setting out the details of a future EU-UK relationship. According to Rule 108(7):

"Parliament shall give its opinion on, or its consent to, the conclusion, renewal or amendment of an international agreement or a financial protocol concluded by the European Union in a single vote by a majority of the votes cast."

This means that, for the purposes of an Article 50 TEU withdrawal agreement, and for any agreement setting out the details of a future EU-UK relationship that is based on Article 218 TFEU, the default rule enshrined in Article 231 TFEU and Rule 168(2) Rules of Procedure requiring a "majority of votes cast" shall apply.

Accordingly, a simple majority of votes cast in a European Parliament consisting of at least one third of the total number of MEPs shall determine the position of the European Parliament.

\section{Influencing Negotiations and the Withholding of Consent}
a.) Overview

Turning to the question of withholding consent, the wording of Article 50(2) TEU appears to provide a clear answer: without European Parliament's consent, there can be no move to a qualified majority vote in the Council and thus the withdrawal agreement cannot be concluded. Should this consent be withheld for the duration of the two-year period running from the moment

\footnotetext{
${ }^{31}$ Hillion (n 17) 140-141; J.C. Piris, "Should the UK Withdraw from the EU: Legal Aspects and Effects of Possible Options", Fondation Robert Schuman Policy Paper, European issues No. 355 (5th May 2015), available at: http://www.robert-schuman.eu/en/doc/questions-d-europe/qe-355-en.pdf.
} 
the UK signals its intention to withdraw, it seems that the UK would once again be facing the prospect of having its EU membership come to an end without an Article 50 TEU agreement.

Of course, should a deal be reached within the two-year period but the European Parliament signals its intention to withhold consent, it is conceivable that this may prompt a move to extend the negotiating period via a unanimous vote of the European Council.

Nevertheless, the question necessarily arises as to whether the European Parliament will be in a position to exert influence upon the content of any withdrawal agreement and/or any agreement detailing future relations between the EU and the UK in light of the obligation for it to provide its consent? ? $^{32}$

Based solely on the wording of Article 50 TEU, it would appear that the European Parliament's role is confined solely to providing consent to the final agreement, thus indicating that it is to take no part in the negotiations leading up to the conclusion of that agreement. Indeed, within the context of the requirement that the Parliament provide consent to international agreements concluded by the EU under Article 218 TFEU, it has been noted that "the European Parliament's consent is only requisite once the agreement has already been signed, which precludes MEPs from influencing the contents of the initial version of the agreement before signature as well as from amending individual provisions thereof after signature. The agreement can only be accepted or rejected in toto" ${ }^{\text {,33 }}$

Whilst formally speaking this is correct, the European Parliament may nevertheless be able to influence the negotiation process and, therefore, the content of the withdrawal agreement prior to it being asked for its consent.

Recent events seem to confirm that this is the view taken by MEPs. In the immediate aftermath of the referendum result, the European Parliament adopted a resolution in which, inter alia, it:

"Recalls that the consent of the European Parliament is required under the Treaties, and that it must be fully involved at all stages of the various procedures concerning the withdrawal agreement and any future relationship. ${ }^{, 34}$

As shall be discussed below, the degree of involvement of the Commission during the process of negotiating the withdrawal agreement will likely impact upon the extent to which Parliament

\footnotetext{
${ }^{32}$ On this point see Hillion (n 17), 141; V. Miller and A. Lang (n 14) 18.

${ }^{33}$ Davor Jancic, 'The European Parliament and EU-US Relations: Revamping Institutional Cooperation?' in Fahey \& Curtin (eds), A Transatlantic Community of Law: Legal Perspectives on the Relationship between the EU and US Legal Orders, (CUP 2014) p.37.

34 European Parliament resolution of 28 June 2016 on the decision to leave the EU resulting from the UK referendum (2016/2800(RSP), available at: http://www.europarl.europa.eu/sides/getDoc.do?pubRef=//EP//TEXT+TA+P8-TA-2016-0294+0+DOC+XML+V0//EN\&language=EN
} 
may influence proceedings (as it will for any agreement setting out the UK's future relationship with the EU.)

\section{b.) The Commission as Negotiator}

As was noted above, Article 50(2) TEU requires that negotiations over the withdrawal agreement be conducted in accordance with Article 218(3) TFEU. Although the precise role of the Commission in the negotiation process is unclear, the wording of Article 50 TEU, when combined with the procedure set out in Article 218(3) TFEU, suggests that the Commission "could be involved in drafting the negotiating mandate, and might possibly be entrusted by the Council with the task of negotiating the withdrawal agreement, or at the very least be part of the negotiating team."35

According to Professor Wyatt in his evidence to the House of Lords European Union Select Committee:

"Under guidelines from the European Council, the Council applies the ordinary rules and sets a negotiating mandate for the Commission. The Commission will negotiate the agreement on the EU side. We have guidelines from the European Council and we have the negotiating mandate from the Council... The result is that the Commission negotiates but the national Governments are in the driving seat, and that will be very political. They will call the important shots." 36

In a similar vein, former Judge at the Court of Justice of the European Union (CJEU) Sir David Edward stated before the same select committee that:

"I would envisage that, formally speaking, the Commission will do the negotiations, but in the way things work I strongly suspect that the Council's internal services will also be closely involved right the way through, as well as the other Member States."37

In terms of how this impacts upon the role of the European Parliament, it is important to note that a detailed framework agreement exists on relations between the European Parliament and the European Commission. ${ }^{38}$

According to that agreement, "Parliament shall be immediately and fully informed at all stages of the negotiation and conclusion of international agreements, including the definition of

\footnotetext{
${ }^{35}$ Christophe Hillion, 'Leaving the European Union, the Union way: A legal analysis of Article 50 TEU', Swedish Institute for European Policy Studies (Sieps), European Policy Analysis, August 2016, 7.

${ }^{36}$ House of Lords European Union Committee (n 4) p.7

${ }^{37} \mathrm{Ibid}, \mathrm{p} .8$; In support of the proposition that the Commission will conduct the day-to-day negotiations see J.C Piris (n 33) p.5.

${ }^{38}$ Framework Agreement on relations between the European Parliament and the European Commission, 2010, OJ/ L 304/47
} 
negotiating directives." ${ }^{39}$ Furthermore, "the Commission shall take due account of Parliament's comments throughout the negotiations" and "the Commission shall keep Parliament regularly and promptly informed about the conduct of negotiations until the agreement is initialed, and explain whether and how Parliament's comments were incorporated in the texts under negotiations and if not why." 40

We therefore have at least two ways in which the European Parliament may influence the content of any withdrawal agreement under Article 50 TEU.

First, the EP has the "nuclear" option of simply withholding consent from the final agreement when it is presented with it. Should matters reach this stage, the Parliament would then be in a position to voice its concerns and demand they be addressed before its consent is requested again.

Second, in light of the prospect of withholding consent, the European Parliament may seek to influence the negotiation process prior to its conclusion.

Whilst this is not explicitly provided for in the wording of Article 50 TEU or Article 218 TFEU, the politics of the situation surely dictate that the input of the European Parliament be sought prior to conclusion of any withdrawal agreement. Simply put, failure to adequately account for the views of Parliament during negotiations are likely to enhance the prospects of it withholding its consent from the final agreement. Indeed, both Sir Edward and Professor Wyatt took the view that the European Parliament's power to refuse to give consent to any draft withdrawal agreement is likely to give it considerable influence in the negotiations. ${ }^{41}$

Consequently, the process is likely to run much more smoothly should the EP's concerns be accommodated during the negotiations than it would if it is simply left out in the cold until its consent is required. The abovementioned framework agreement provides a structured means through which the EP may exert influence in this regard.

c.) Parliament's Track Record

Furthermore, past experience demonstrates that the European Parliament is likely to have a real influence on the process of negotiating and ultimately concluding any withdrawal agreement (and any future EU-UK relationship deal for that matter.)

As De Baere notes, following the entry into force of the Lisbon Treaty:

\footnotetext{
${ }^{39}$ Ibid, point 23.

${ }^{40}$ Ibid, Annex III, points 3 and 4.

${ }^{41}$ House of Lords European Union Committee (n 4) p. 7-9
} 
"The Parliament has been keen to demonstrate its increased powers not just in the area of external trade, but in all areas in which its consent is mandatory." 42

These increased powers were amply demonstrated during the Spritzenkandidat process which took place in the build-up to the 2014 European Parliamentary elections.

According to the procedure introduced by the Lisbon Treaty and set-down in Article 17(7) TEU, the European Council shall propose to the European Parliament a candidate for President of the Commission "taking into account the elections to the European Parliament." Having been presented with a candidate, the European Parliament shall move to elect him/her by a majority of its component members.

As has been well documented, this provision was utilized by the European Parliament during the 2014 elections to urge the European political parties to nominate candidates for the position of President of the Commission. ${ }^{43}$ This had the effect of "transforming the European elections also into a vote for the President of the Commission." 44

Furthermore, it directly contrasted with the views of many national governments, who believed that they remained in charge of the process of selecting the next person to head the Commission via the European Council.

Following the results of the elections in which the European People's Party won the most seats, however, the European Parliament moved quickly to present Juncker as the democratically legitimate choice as Commission President. ${ }^{45}$ Once Juncker's nomination had been confirmed, it was noted that "the European Parliament won an important victory in the inter-institutional battle for power. By imposing one of the Spitzenkandidaten as the European Council's nominee for Commission President, the Parliament set an important precedent for the future, which weakens the power of the European Council to select its own preferred candidates."46

In addition to this demonstration of political power, the European Parliament has also played a Comment [DH2]: Once again, if short on space, the Spitzenkandidaten process section could be cut. -350 words crucial role during the negotiation and conclusion of many international agreements in recent years.

${ }^{42}$ G.D. Baere 'EU external action', in Barnard and Peers (eds), European Union Law (Oxford 2014) 736.

${ }^{43}$ Marco Goldoni, 'Politicising EU Lawmaking? The Spitzenkandidaten Experiment as a Cautionary Tale, (2016) 22(3) European Law Journal, 286-287.

${ }^{44}$ Joana Mendes, 'The Democratic Foundations of the Union: Representative Democracy, Complementarity and the Legal Challenge of Article 11 TEU' in Łazowski and Blockmans (eds) Research Handbook on EU Institutional Law, (Edward Elgar, 2016) 159-160.

${ }^{45}$ For an overview see Honor Mahony, 'The Spitzenkandidaten Coup', EU Observer, $4^{\text {th }}$ Jan 2015, available at: https://euobserver.com/review-2014/126456.

${ }^{46}$ S.Hobolt, 'The Role of Spitzenkandidaten in the 2014 European Parliament Elections', (2014) 10 Journal of European Pubic Policy, 1538. 
A pertinent illustration of the European Parliament's power and influence in this regard came from its decision to withhold consent from the EU-US Agreement on the processing and transfer of Financial Messaging Data from the EU to the US for the purposes of the Terrorist Finance Tracking Program. ${ }^{47}$

Exercising the power accorded to it by the Lisbon Treaty to provide or withhold consent from international agreements based on Article 218 TFEU, the EP took the view that its consent could not be given to the Agreement amid concerns related to privacy, proportionality and reciprocity. ${ }^{48}$

In the words of the EP's press release, "This move renders the text signed between the US and the 27 EU Member states legally void." ${ }^{, 49}$ Following this withholding of consent, amendments were made to the original agreement before being sent back to the European Parliament which duly provided its consent having been satisfied that its concerns had been satisfactorily addressed. ${ }^{50}$

A further example of the European Parliament exerting influence over international agreements in the post-Lisbon Treaty era came in 2011 during the renegotiation of the Passenger Named Record (PNR) agreement between the EU and the United States. ${ }^{51}$ PNR data are collected by air carriers during the reservation process and include names, addresses, credit card details and seat numbers of air passengers. Under the initial agreement, EU airlines flying into the US were obliged to provide US authorities with PNR data held in their reservation systems after the departure of a flight. ${ }^{52}$ Transfer of information of this nature was seen as a necessary component in the fight against terrorism following the $9 / 11$ atrocities. ${ }^{53}$

\footnotetext{
${ }^{47}$ European Parliament legislative resolution of 11 February 2010 on the proposal for a Council decision on the conclusion of the Agreement between the European Union and the United States of America on the processing and transfer of Financial Messaging Data from the European Union to the United States for purposes of the Terrorist Finance Tracking Program (05305/1/2010 REV 1 - C7-0004/2010 - 2009/0190(NLE)).

${ }^{48}$ E Fahey, 'Law and Governance as Checks and Balances in Transatlantic Security: Rights, Redress, and Remedies in EU-US Passenger Name Records and the Terrorist Finance Tracking Program' (2013) 32 Yearbook of European Law 368, 379; J Monar, 'Guest Editorial: Rejection of the EU-US SWIFT Interim Agreement by the European Parliament: A Historic Vote and Its Implications' (2010) 15 (2) European Foreign Affairs Review 143.

${ }^{49}$ European Parliament, 'SWIFT: European Parliament Votes Down Agreement with the US' Justice and Home Affairs Press Release, 11 February 2010, available at:

http://www.europarl.europa.eu/sides/getDoc.do?language=en\&type=IM-PRESS\&reference=20100209IPR68674

${ }^{50}$ Davor JančIć, 'Transatlantic Regulatory Interdependence, Law and Governance: The Evolving Roles of the EU and US Legislatures' (2015) 17 Cambridge Yearbook of European Legal Studies 334, 339.

${ }^{51}$ European Commission, 'Frequently asked questions: the new EU-US agreement on the transfer of Passenger Name Record (PNR)' 17 November 2011, MEMO/11/797.

${ }^{52}$ Agreement between the European Community and the United States of America on the processing and transfer of PNR data by Air Carriers to the United States Department of Homeland Security (DHS), Bureau of Customs and Border Protection ([2004] OJ L183/83, and corrigendum at [2005] OJ L255/168);

${ }^{53}$ Fahey (n 49) 369.
} 
In May 2010, in light of concerns mainly about data protection, the European Parliament postponed its vote on a PNR agreement with the US that had applied provisionally since 2007, thus demonstrating its powers under the consent procedure accorded to it by the Lisbon Treaty under Art 218(6)(a) TFEU. ${ }^{54}$ "MEPs then urged the European Commission to negotiate a new deal, which the Commission did in 2011." "leading part in bringing about a change" to the ways in which the relevant US authorities can access the flight data of EU citizens. ${ }^{56}$

The European Parliament has also demonstrated its willingness to exercise its powers during the conclusion of the multilateral Anti-Counterfeiting Trade Agreement (ACTA), which sought to establish global mechanisms for the enforcement of copyright laws. Prior to voting on whether to provide or withhold its consent to the deal, the EP's committee on Civil Liberties, Justice and Home Affairs raised concerns about the lack of transparency with which the negotiations had been conducted and, in particular, the failure to keep Parliament immediately and fully informed at all stages of the negotiation procedure. Ultimately, these shortcomings, coupled with concerns about civil liberties led to the EP refusing to give consent to the deal. ${ }^{57}$ "This testified to the MEPs' efforts to defend EU values and alert foreign partners that its standpoints need to be given due regard. ${ }^{, 58}$

In light of these examples, it is foreseeable that the EP will seek to ensure that both its own interests and those of EU citizens which it is mandated to represent under Article 10(2) TEU are adequately protected within the context of negotiating and concluding any Article 50 TEU agreement.

To take but one example, should the UK government fail to explicitly guarantee a right to remain to those EU citizens currently living and working in the UK, it is possible that the EU Parliament would indicate an unwillingness to provide its consent to any withdrawal agreement that did not address this issue.

\section{d.) Future Prospects}

\footnotetext{
${ }^{54}$ ibid 374

55 'Parliament gives green light to air passenger data deal with the US'. Available at: «http://www.europarl.europa.eu/news/en/pressroom/content/20120419IPR43404/html/Parliament-gives-green lightto-air-passenger-data-deal-with-the-US».

${ }^{56}$ Yuko Suda, 'Transatlantic Politics of Data Transfer: Extraterritoriality, Counter-Extraterritoriality and CounterTerrorism: Transatlantic Politics of Data Transfer' (2013) 51 JCMS: Journal of Common Market Studies 772, 780.

${ }^{57}$ European Parliament legislative resolution of 4 July 2012 on the draft Council decision on the conclusion of the Anti-Counterfeiting Trade Agreement between the European Union and its Member States, Australia, Canada, Japan, the Republic of Korea, the United Mexican States, the Kingdom of Morocco, New Zealand, the Republic of Singapore, the Swiss Confederation and the United States of America (12195/2011 - C7-0027/2012 2011/0167(NLE)).

${ }^{58}$ JančIć (n 51) 347.
} 
Returning to matters of procedure, it is interesting to note that Article 50(2) TEU simply stipulates that the consent of the European Parliament must be obtained before the Council may move to conclude the withdrawal agreement. It does not provide a time limit within which that consent must be obtained or withheld. According to Chalmers et al, Parliament has "an indefinite time" within which to provide its consent in situations where it is required, thus raising the prospect of the Parliament simply abstaining from either granting or withholding such consent until the end of the two-year time limit. ${ }^{59}$

However, under Article 218(6)(a) TFEU, which governs the conclusion of international agreements, "The European Parliament and the Council may, in an urgent situation, agree upon a time limit for consent." Operating on the assumption that the withdrawal agreement under Article $50 \mathrm{TEU}$ would constitute a specific type of international agreement for the purposes of Article 218 TFEU, it remains to be seen whether its conclusion would be categorized as "urgent" for these purposes.

In light of these observations, the role of the European Parliament is not to be taken lightly during any withdrawal agreement negotiations in the months and years that follow - not least because national governments will have much less control over their MEPs than their representatives in the European Council and the Council. Indeed, as Łazowski has noted:

"The experience of recent years proves it is likely that the European Parliament will have no desire to remain a passive actor in such negotiations and the formal assent may mean far more than a mere 'yes or no.",60

This potentially brings an additional and as yet largely unexplored question to the table regarding the role that Scotland (and perhaps Northern Ireland) can play in the Article 50 withdrawal process.

Following the decision of the people of Scotland to vote overwhelmingly in favour of the UK remaining in the EU, the Scottish Parliament passed a resolution which mandated:

"the Scottish Government to have discussions with the UK Government, other devolved administrations, the EU institutions and member states to explore options for protecting Scotland's relationship with the EU, Scotland's place in the single market and the social, employment and economic benefits that come from that, and instructs the Scottish Government to report back regularly to parliamentarians, to the European and External Relations Committee and the Parliament on the progress of those discussions and to seek Parliament's approval of the outcome of that process." ${ }^{\prime \prime 1}$

\footnotetext{
${ }^{59}$ Chalmers et al (n 4) 127.

${ }^{60}$ A. Łazowski, (n 8) 528.

${ }^{61}$ Nicola Sturgeon, "Implications of the EU Referendum for Scotland", Scottish Parliament Motion S5M-00601 $(27 / 06 / 2016)$, 
This has raised the question of how much can be done by the devolved governments of the UK to protect their trade and other relationships with the European Union both during the withdrawal agreement negotiations and after it takes effect. ${ }^{62}$

Accordingly, whilst it may not be possible as a matter of UK domestic law for the devolved governments to block a "Brexit", ${ }^{63}$ there would appear to be scope for Scottish and Irish MEPs to begin building alliances across the European Parliament to withhold consent from any future withdrawal agreement lest their interests be protected. ${ }^{64}$

The great risk with this, of course, is that the European Parliament withholds consent, no extension to the negotiations is agreed in the European Council, and Scotland, with the rest of the $\mathrm{UK}$, leaves the EU with nothing.

\section{Would UK MEPs Vote?}

A further question to be considered within the context of the role of the European Parliament is whether MEPs returned from UK constituencies to serve during the 2014-2019 European Parliamentary term would be able to vote on the withdrawal agreement.

According to Article 50 (4) TEU:

"For the purposes of paragraphs 2 and 3, the member of the European Council or of the Council representing the withdrawing Member State shall not participate in the discussions of the European Council or Council or in decisions concerning it."

This makes sense given that the European Council sets out the guidelines for negotiating the Article $50 \mathrm{TEU}$ withdrawal agreement with the withdrawing state and the Council is involved in the concluding of such an agreement. It would therefore be bizarre for members of the UK government to be sitting in the European Council or Council opposite the UK's negotiating team in any withdrawal negotiations.

http://www.parliament.scot/parliamentarybusiness/28877.aspx?SearchType=Advance $\&$ ReferenceNumbers=S5M$00601 \&$ ResultsPerPage $=10$.

${ }^{62}$ A. O’Neill QC “England's Difficulty; Scotland's Opportunity” Eutopia Law Blog, June 28, 2016, available at: https://eutopialaw.com/2016/06/28/englands-difficulty-scotlands-opportunity/.

${ }_{63}$ Mark Elliott, "Can Scotland Block Brexit?", Public Law for Everyone Blog, 26 June 2016, available at: https://publiclawforeveryone.com/2016/06/26/brexit-can-scotland-block-brexit/.

${ }^{64}$ For the European Parliamentary term 2014-2019 Scotland was treated as a single electoral constituency and returned 6 MEPs to the European Parliament. Two are members of the Scottish National Party. Two are members of the Scottish Labour Party. One is a member of the Conservative Party. One is a member of the United Kingdom Independence Party. For the same Parliamentary term, Northern Ireland was also treated as a single electoral constituency and returned 3 MEPs to the European Parliament. One is a member of Sinn Féin. One is a member of Ulster Conservatives and Unionists. One is a member of the Democratic Unionist Party. 
As Hillion notes, however, if Article 50(4) TEU is interpreted in reverse, the conclusion seems to be a rather paradoxical one; namely, that the withdrawing state is authorized to continue participating in all other Council and European Council discussions and decisions. ${ }^{65}$ Whilst formally speaking this would appear to be correct given that a withdrawing state remains a Member State until either the Article 50 TEU withdrawal agreement enters into force or the twoyear time period elapses, "it is questionable whether, from the perspective of democratic legitimacy, it should nevertheless be entitled to influence EU decisions which might never apply to it, or indeed use its position to obtain concessions in the context of the withdrawal negotiations." 66

What is more significant than the role of the UK's representatives in the European Council and the Council for present purposes, however, is that nothing is said in Article 50(4) TEU about the MEPs of the withdrawing state participating in the withdrawal agreement negotiations and/or vote to conclude in the European Parliament.

Will the UK's MEPs be involved in the vote to give consent to the withdrawal agreement prior to moving to Qualified Majority Voting in the Council?

According to one commentator, despite Article 50 TEU being silent on this, it seems "reasonable to expect that the same rule will apply to the elected members of the European Parliament from the departing country" as applies to members of the Council and European Council. ${ }^{67}$

In contrast, others have reached the opposite conclusion, contending that the Treaties do not prevent those MEPs elected in the withdrawing Member State from participating in either Parliamentary debates or in its committees, or from voting on the Parliament's motion to provide its consent to the withdrawal agreement. ${ }^{68}$ This flows from Article 10(2) TEU which provides "Citizens are directly represented at Union level in the European Parliament" - indicating that the role of MEPs is to represent the interests of EU citizens as a whole and not merely those of the Member State in which they were elected. ${ }^{69}$

The latter view seems persuasive, and a possible indication of how this may play out in future was provided by the abovementioned European Parliament briefing note of February 2016 in which it was stated that:

\footnotetext{
${ }^{65}$ Hillion (n 38) 5.

${ }^{66} \mathrm{Ibid}$.

${ }^{67}$ A. Łazowski, (n 8) 528

${ }^{68} \mathrm{C}$ M Rieder, "The withdrawal clause of the Lisbon Treaty in the light of EU citizenship: between disintegration and integration", (2013) Fordham International Law Journal, Vol. 147, 147, 158.; Hillion (n 17) 138.

${ }^{69} \mathrm{C}$ M Rieder (n 31) 158; For doubts as to whether the European Parliament in its current form may meet the ideal of representative democracy see the decision of the German Constitutional Court in Gauweiler $v$ Treaty of Lisbon (BVerfG, 2 BvE 2/08, Judgment of 30 June 2009), paras 280-289.
} 
"The composition of the EU institutions could be expected to change as of the day the withdrawal takes effect, with members from the withdrawing state losing their seats in the various institutions and bodies, although transitional arrangements might be required for the period immediately after that date." 70

This suggests that, until the day on which the withdrawal agreement enters into force, UK MEPs will continue to participate in the workings of the European Parliament and, as a consequence, vote on any withdrawal agreement.

\section{Can the European Parliament Seek Judicial Review before the Court of Justice?}

A final point to consider during the withdrawal agreement negotiations would be whether the European Parliament may seek judicial review of any proposed withdrawal agreement before the Court of Justice of the European Union to ascertain whether its provisions are compatible with the EU legal order?

From a hierarchy of norms perspective, it is clear that, unlike accession agreements under Article 49 TEU, any withdrawal agreement concluded under Article 50 TEU would not constitute primary EU law and its legality would therefore be subject to the CJEU's jurisdiction.

Neither Article 50 TEU nor Rule 82 of the Parliament's Rules of Procedure which govern withdrawal agreements address this possibility. However, the reference in Article 50(2) TEU to the procedure for concluding international agreements under Article 218(3) TFEU suggests that any withdrawal agreement would constitute an international agreement for the purposes of that latter provision. ${ }^{71}$

In light of this, Article 218(11) TFEU provides that:

"A Member State, the European Parliament, the Council or the Commission may obtain the opinion of the Court of Justice as to whether an agreement envisaged is compatible with the Treaties. Where the opinion of the Court is adverse, the agreement envisaged may not enter into force unless it is amended or the Treaties are revised."

The procedure for requesting such an opinion from the Court is governed by Rule 108(6) of the European Parliament's Rules of Procedure which states that before any vote is taken on giving consent to an international agreement,

"the committee responsible, a political group or at least one-tenth of the Members may propose that Parliament seek an opinion from the Court of Justice on the compatibility of

\footnotetext{
${ }^{70}$ Poptcheva (n 3).

${ }^{71}$ J.C. Piris (n 33) p.5-6, available at: http://www.robert-schuman.eu/en/doc/questions-d-europe/qe-355-en.pdf.
} 
an international agreement with the Treaties. If Parliament approves such a proposal, the vote shall be adjourned until the Court has delivered its opinion."

As a result, a meagre 75 MEPs may be table a proposal seeking an opinion on the legality of any future UK-EU withdrawal agreement from the CJEU.

Two questions arise here: First, how does the European Parliament 'approve' such a proposal? And second, would the seeking of an opinion from the CJEU also impact upon the two-year time limit set down in Article 50(2) TEU?

With regards to the requesting of a Court opinion, in the absence of any detailed rules to the contrary, it would appear to be the case that the default voting rules of the Parliament as set down in Article 231 TFEU and Rule 168(2) Rules of Procedure would apply. Consequently, following a proposal to request an opinion from the CJEU via one of the mechanisms detailed in Rule 108(6) Rules of Procedure above, the European Parliament may approve or reject such a proposal by a majority vote of one thirds of its members.

Turning to the issue of the two-year time limit within which a withdrawal agreement must be reached, it is unclear from both the Treaties and the Rules of Procedure whether the request for a CJEU opinion would have the effect of stopping the clock pending the CJEU's decision. What is clear, however, is that the European Parliament cannot vote to give or withhold its consent from the withdrawal agreement while the CJEU's decision is pending. Under Rule 108(6) Rules of Procedure "If Parliament approves such a proposal, the vote shall be adjourned until the Court has delivered its opinion."

In the event that a request for an opinion did indeed stop the Article 50 TEU clock, this may not cause too many problems - the two-year time limit would re-start once the CJEU had rendered its decision and the European Parliament would then move to give or withhold its consent (provided that the agreement is upheld.)

Should the alternative situation arise, however, and the time-limit continues to run despite the European Parliament postponing its vote pending a CJEU decision, it is possible that the European Parliament may force a clean break off of relations between the EU and the UK by requesting an opinion from the Court which is not answered before the two-year deadline expires.

Once again, it would of course be open to the European Council to unanimously vote to extend the two year negotiating period should such a reference arise. 
In terms of the substance of any request of an opinion, it would be open to the European Parliament to ask the Court to determine whether the agreement as a whole or specific aspects of it complied with any provision of the EU Treaties. ${ }^{72}$

Finally, the prospects of litigation against the withdrawal agreement by the European Parliament would not be removed by its providing of consent to the final deal reached. According to Article 263(2) TFEU, the European Parliament may seek to bring an action of annulment against any aspect of the agreement once it has entered into force. Of course, having consented to the withdrawal agreement, it would then be rather odd for the EP to challenge its legality before the Court. However, as a matter of procedure, there is nothing in principle which would stop the Parliament from doing so. ${ }^{73}$ As is made plain by Article 19(1) TEU, Article 263 TFEU and established jurisprudence, the Court has exclusive jurisdiction and thus the final say on the legality of measures of Union law. ${ }^{74}$

\section{Conclusion}

The role that the European Parliament may play in the negotiation and conclusion of a withdrawal agreement between the UK and the EU following the UK's decision to vote to leave the EU has been largely overlooked in the immediate aftermath of the referendum.

As this paper has tried to demonstrate, Article 50 TEU, coupled with the relevant provisions of the European Parliament's Rules of Procedure, provide ample opportunities for the EU's only directly elected institution to exert considerable influence over final outcome of the UK's withdrawal process.

Indeed, a strong indication that the European Parliament stands ready to play an active role in proceedings was recently provided by its President Martin Schulz, who stated that

"[T]he European Parliament, will play a key role in setting the new relationship between the EU and the UK - not least because we must consent to any withdrawal treaty and subsequent treaty setting out the full relationship. And everyone wants to avoid the experiences we had a few years ago - which some of you may remember as the so-called

\footnotetext{
72 Opinion 2/94, EU:C:1996:140, paragraph 3; Opinion 1/08, EU:C:2009:739, paragraph 107; Opinion 1/09, EU:C:2011:123, paragraph 47; Opinion 2/13, EU:C:2014:2454, para 145.

${ }^{73}$ This much has been implicitly accepted by the Court in previous requests of opinions, see Opinion 2/13, para 146 and case law cited therein.

${ }^{74}$ Case 314/85, Foto-Frost [1987] ECR 4199.
} 
TFTP (SWIFT) and ACTA cases - where the Parliament's priorities were not reflected in the negotiations and it decided to veto the final deal." ${ }^{, 75}$

Once the wheels are in motion, it may well transpire that it is the Members of the European Parliament, and not, as many expect, the representatives of the 27 Member State governments in the Council, who prove to be the greatest obstacle to any future UK-EU deal.

\footnotetext{
${ }^{75}$ Martin Schulz, 'The EU and the UK - Parting Ways but Working Together', speech at the European Institute of the London School of Economics, 23 September 2016, available at: http://www.europarl.europa.eu/thepresident/en/press-room/the-eu-and-the-uk-\%E2\%80\%93-parting-ways-but-working-together-speech-at-theeuropean-institute-of-the-london-school-of-economics.pdf
} 